\title{
RESEARCH OF NOTE
}

\section{Telling the Story of \\ Islam in Asia: \\ Reflections on Teleologies and Timelessness}

\author{
Barbara D. Metcalf \\ University of Michigan
}

\section{Introduction: The importance of Islam in Asia}

Any of us who teaches about Muslims in Asia is likely to feel the need to insist on the importance of the subject and its neglect by people who reduce Islam and its adherents to the Middle East or conflate Muslim and Arab. ${ }^{1}$ The chart of population figures listed in the appendix shows why, in terms of the sheer numbers involved, one might want to assert Asia's importance as the four largest Muslim populations in the world: Indonesia, Pakistan, India, and Bangladesh are in Asia. The largest concentration of Muslims anywhere is in the area we demarcate "South Asia," the old British India with close to half a billion population of Muslims. Approximately one in three of the world's Muslims lives in the first set of countries listed in the appendix.

The population statistics within countries that automatically click "Islam" in people's minds just don't compare. Saudi Arabia may have a population of twenty-eight million, all Muslim, but Uttar Pradesh, the state I primarily study in the Republic of India, with only an eighteen percent Muslim population, has about six million more, some thirty-four million.

Numbers aside, sadly many of these areas have in fact come into popular purview in recent years because of war, violence, and strategic considerations. Afghanistan and Pakistan are widely considered as among the most dangerous places geopolitically in the world, and American troops are deeply 
involved in the on-going fighting there. No country has matched Pakistan as far as I know in the illegal dissemination of nuclear technology. Terrorist blasts put idyllic Bali on the map. Territorial and culturally-distinctive separatist movements, some of which morph into Islamically defined movements, have been endemic in Kashmir, effectively now divided between India and Pakistan. They are persistent in the southern Philippine area and, more recently evident in Thailand. The new "stans" of Central Asia have also come into our consciousness in recent years, a consciousness defined primarily by fears of draconian militancy.

In many areas of Asia, Muslims have been significant victims of violence. This has been true for the Muslim population of western and southwest China, where Muslims have suffered human rights abuses, as they shockingly have in India, where anti-Muslim pogroms, notably in 1992 and 2002, killed thousands and shocked a world otherwise so appreciative of India's democracy.

An important characteristic of many Muslim populations in Asia is their location within religiously plural societies and the fact that in many cases they form minority populations. The biggest countries of the Middle East, like Egypt, Turkey, or Iran, are $90 \%$ or more Muslim-Egypt is $90 \%$, the other two almost $100 \%$ - as are others in the region. In contrast, as shown on the population chart, in most of these countries in Asia, Muslims live with populations of varied religious backgrounds. The only country on the list that is $100 \%$ Muslim is the tiny island Maldives (whose existence, global warming puts at risk!). Only Pakistan and Afghanistan merge with their western neighbors as countries of primarily Muslim populations, and Pakistan, like Bangladesh, has the proportion of Muslims it does because of the 1947 partition of British India that drew international boundaries precisely in order to separate out contiguous areas of majority Muslim populations. Bangladesh, like Indonesia, has a nonMuslim population of $15-20 \%$. 


\section{Historical stories as the key to interpretations of "Islam" and Naipaul's version:}

Interpretations of the origins of Muslims in South Asia and of the nature of Islam in these culturally pluralistic contexts typically revolved around stories that are largely historical. These stories often entail stereotypical thinking about Muslims, and are uniformly forged in the context of modern nationalisms. The recognition that these historical stories are as much "political" as they are "scientific," is a problem that dogs not only our teaching and research on Muslims in Asia but that in varying ways engages profound issues in public life. Historical narratives as nationalist myths become part of one's common sense and are profoundly difficult to dislodge. That is the reason why it seems to me that the history alluded to in my title, "telling the story of Islam in Asia," matters so much to our teaching. Ideologies that underly nationalism, which worldwide have involved a most powerful loyalty of the recent past, shape history and culture in the direction that presumes the existence of shared national characteristics and cultural homogeneity. Those characteristics may be defined in relation to external powers or in response to internal populations whose existence is seen as problematic. However told, at the core of any nationalist ideology is, a collective biography that tells a version of the genetic continuity of a collective life. It is "timeless" in the sense of reading present values and loyalties anachronistically into the past; it is "teleological" in its development toward the present.

V. S. Naipaul, the Trinidad-born, Sussex-settled, Nobel prize winning author of Brahmin and Indian-indentured labor heritage crafted one deceptively persuasive story about Muslims in the broad swathe through southern Asia-Pakistan, India, Malaysia, Indonesia-a story that turns out to be one of "Western" difference forged precisely, as we have learned long since from Edward Said, by projecting all that the narrators reject onto their own version of an "East," often equated with "Islam." European nationalisms were shaped in a context of selfdistinction from populations, including those they conquered, that were seen as trapped in a distant past characterized above 
all by "religion" that determined all they did. Islam, at times admired for its monotheism, more typically was excoriated for fanaticism, despotism, and irrationality.

In the aftermath of the Iranian revolution of 1979, that so shook the certainties of Cold War politics and the rationality of market logic, Naipaul travelled via Iran on into South Asia, Indonesia, and Malaysia. His subsequent book, Among the Believers, told its readers what they wanted to hear. Presented as the work of a mere transmitter, a listener telling us "just the facts," Naipaul, the voice of Enlightenment reason, depicted "Islamic" rage and resentment, for which, as the anthropologist Michael Gilsenan puts it, "this one-dimensional, historically unvarying 'Islam' has a special affinity" (Gilsenan 1998). The story of the Iranian revolution as one of unbridled fanaticismnot, for example, as a story of a non-violent revolution against Iranian and foreign exploitation-led America, for example, to its support of Saddam Hussein in his ghastly unprovoked war against Iran and continues to distort foreign policy in the region. Naipaul's credibility to Euro-American readers was double, simultaneously a brilliant writer and himself sufficiently part of an undifferentiated "other" that he must be right.

Naipaul's history thus had a timeless "Islam" as its motor. The historical experiences of colonialism, the north-south divide, and incipient globalization had little place in his narrative.

Almost 20 years later, in the late 1990s, Naipaul returned to Iran, and also to Indonesia, Malaysia, and Pakistan and wrote Beyond Belief (1998), a work that evoked his earlier title"among the believers." Now his issue proved not only to be Islam - the timeless Islam of rage and resentment—but also, as his subtitle put it, in isolating a second historical theme as key for the experience of all these diverse peoples: Islamic Excursions among the Converted Peoples. [underline added] Not only is Naipaul's timeless Islam a dark blot of fanaticism, but in all these non-Arab speaking countries, Islam is a layer, an archaeological stratum, an undigested deposit over the authentic, the indigenous, the real, that leaves its followers dislocated and alienated from self and place. This is certainly a scary story, a depiction of Islam beyond the Arab world as a 
simmering volcano, a place where Muslims are particularly likely to cultivate extremes, whether of fanaticism or violence.

It is a truly astonishing argument. How can Naipaul attribute this imagined fractured "conversion" to one religious tradition and one part of the world? To do so, he must ignore the way that cultural change takes place everywhere as new symbols come to give meaning to changing contexts, and all cultures reinvent themselves over time. He must imagine some rigid "Islam" that arrives fully formed in every place. And he must not only be imagining conversion as some sort of dramatic fracture - already a leap_-but also assume that some residual culture is passed on through some kind of genetic memory. Naipaul clearly never heard what I think may be the most useful single sentence any history teacher-in this case Philip Curtin (the distinguished historian of Africa) said to me during my first year of graduate work - "Never forget, 'tradition' is exactly one generation old."

What gives Naipaul's argument some plausibility, I think, is that that some version of his view of "foreign" and "layering" is in fact a relentless theme in colonial-era historiography. Among Muslims and others forging modern reform movements, it has been supported by ideologies invoking identity politics, and nationalist myths. These modern visions are, I would argue, not actual descriptions of historical experience but rather subjects that need to be historicized in the context of modern societies.

\section{Asking what purposes a story serves: the British colonialist story, the nationalist echo}

If we buy the Naipaul-style story of cultural layers, we are trapped into a particular set of questions, like what is foreign, i.e. "really" Islamic, and what is local. Once we move beyond that layered approach to culture, we can ask other kinds of questions. Of these, a central one is how symbols and interpretations actually work for those who embrace them. Historical stories about Muslims and about Islam in British India, for example, were useful. The locus classicus for the colonial story is the History of India as Told by its Own Historians, first published in 1849, a compilation of translated selections in 
eight substantial volumes, taken from Persian (and some Arabic) sources. It does not take any sleuthing to see what was at stake in preparing these translations. Sir Henry M. Elliot wrote as follows about the period of Muslim dynasties in his preface to the first volume:

The common people must have been plunged into the lowest depths of wretchedness and despondency. The few glimpses we have, even among the short Extracts in this single volume, of Hindus slain for disputing with Muhammadans, of general prohibitions against processions, worship, and ablutions, and of other intolerant measures, of idols mutilated, of temples razed, of forcible conversions and marriages, of proscriptions and confiscations, of murders and massacres, and of the sensuality and drunkenness of the tyrants who enjoined them, show us that this picture is not overcharged.... ${ }^{2}$

Elliot had no doubt about the purpose of these translationstotally ignoring the fact that they were isolated from their original context, transformed by translation, and taken not in their rhetorical context but as positivist fact. The translations, Elliot wrote, "[would] make our native subjects more sensible of the immense advantages accruing to them under the mildness and the equity of our rule." 3 India was "Hindu," equally undifferentiated "Muslims" were foreign, and if you believed his version of a period that ignores urbanization, population growth, a renaissance of Sanskrit literature, and the emergence of modern Hinduism's most beloved text (the $16^{\text {th }}$ century Ramcaritmanas)_you can agree with his conclusions. The colonialist story in turn would find its way into important themes of fiction, Hindu reform movements (imputing deviance to Muslim influence), and nationalist rhetoric, and, in those contexts, it would serve to provide the negative to all that was good about "Indian" culture.

Let me turn here to an example of one of the key actors in Elliot's drama. In the mid- $11^{\text {th }}$ century, Mahmud, head of a 
Turkish-Afghan kingdom based in an urbane and cultivated court in Ghazna, in current day Afghanistan, conducted raids as far as the coastal area of Gujarat. Now, he also tried to conquer Muslim-ruled lands to the west, a fact often forgotten in the colonial tale. Mahmud was a favorite of British historians as well as a subject of Hindu nationalist histories, which fixated on Mahmud's raids as a handy metonym for nothing less than the imagined destruction of Hindu civilization by Muslims as a whole.

Recently, the distinguished historian of early India, Romila Thapar, rewrote the story of Somnath. What she did, in a sense, was to make Mahmud simply ordinary. To begin with, she placed Mahmud's raids of the $11^{\text {th }}$ century in the context of what, by that period, could be called "a warrior culture" throughout the Indian subcontinent, when, for example, genealogies, epics, and folklore celebrated warfare and valor on all sides. Mahmud and the Ghaznavids at one end of the subcontinent were, after all, contemporaries of the great Chola dynasty of the southeast, a Hindu dynasty celebrated by Indian nationalists. But the Cholas were conquerors as well, with their power extending from the Maldives across the south, with raids and conquests far north into Orissa and beyond, and eastwards toward southeast Asia.

Mahmud's raids at the time were simply not at all the defining moment they became in modern nationalist ideology. This is clear, Thapar argues, from contemporaneous texts and epigraphy. Mahmud did indeed seize the wealth of Hindu temples, but he was only one of many raiders, including pirates, Hindu rajas, and others, who were lured by the prosperous coast and fertile hinterland of the northwest. Temples, as active sites of accumulation and investment of wealth, were always a major magnet for warrior plunder. It is also noteworthy, lest one assume, as nationalist histories do, a monolithic "Islam," that Mahmud justified his incursions into the subcontinent on the grounds that some of the rulers adhered to the Shi 'i Isma 'ili and Qarmatian heresies_-so his targets were many.

It was later chroniclers of the Turko-Afghan rulers, two to three hundred years after the fact, Thapare points out, who embroidered Mahmud's career to make him a great iconoclast 
and hero of Islam and add legitimacy to the heritage of their respective sultans. It is these accounts, extracted from the ideological contexts of their production, that are read as fact about an imagined past. Thapar in contrast makes Mahmud part of the context of his times in which his fundamental strategies of rule are not fundamentally Islamic and in which the boundaries of contemporary territorial nationalism have no place.

The British did not stop with words. In the midst of the unmitigated disaster of the First Afghan War that took place from 1839 to 1842, India's Governor-General Ellenborough ordered one of his generals to secure a set of gates from Ghazna on the grounds that they were the very gates looted from one of Mahmud's primary targets, the temple at Somnath in Gujarat. Ellenborough issued a triumphant declaration that the return of these gates meant that an "insult of 800 years is at last avenged." The idea that a category of people called "Indian" had harbored a grievance continuously over eight hundred years (Davis 1997: 201-02) is as implausible as Naipaul's formulation of Islamic angst over conversion over all those centuries. Ellenborough, however, organized a ceremony to welcome the gates, and then had them carried in procession across India in anticipation of their "reinstallation" in Gujarat. Of the many reasons why this scheme was misplaced, it soon became apparent (even if kept under wraps), was that the gates not only had no connection with Somnath but none with Gujarat at all (Davis 1997: 209)

Performative history at Somnath was to have a second chance. The ground had been laid over several decades by an idealization of "pre-Islamic" India, as it was imagined, as part of a strand of political rhetoric and blockbuster historical fiction in Indian nationalism. Then, in a triumph of this current within the explicitly secular nationalist movement, shortly after Indian independence, a project was undertaken to actually "rebuild" a temple at Somnath. Even Dr. Rajendra Prasad, the president of India, over the objections of Prime Minister Nehru, who was deeply commited to secularism, subsequently attended the ritual inauguration of the new temple. And the language used on that 
occasion depicted Muslims as foreign and emphasized the importance of the recovery of Indian self-respect. The implications from the whole undertaking were that Hindus were the real natives and the real citizens of India, a perspective little different from that of the British a century before.

The histories created in the colonial period are thus not academic. Mahmud's story reached its climax, in a sense, with an even more dramatic post-colonial intervention in history. This was a procession in 1990 involving another allegedly historical figure, the god Ram, who was launched in a "chariot" from Somnath to Ram's purported birthplace in Ayodhya, the site of a $16^{\text {th }}$ century Mughal mosque.. A campaign to destroy the mosque, of which the procession was a key element, culminated two years later when a well-organized crowd of hundreds of participants, inspired by Hindutva ("Hinduness") destroyed the mosque by hand. The retelling and reenactment of these historical stories does not occur in a vacuum but is brought to life and serves functional ends in specific social and political contexts. The episode of the mosque destruction, for example, was a call to Hindu unity at a time of social unrest among disadvantaged lower strata of society. A call to Hindu unity displaced those tensions onto the Muslim population, imagined as both a historic and present threat. It led to an anti-Muslim pogrom that felt its impact most dramatically in the great city of Mumbai, hundreds of miles distant from the now destroyed mosque.

\section{An alternate nationalism}

There is a second historical story about Muslims in South Asia: a story equally nationalist, equally in need of historicization, namely the story that Islam in this part of the world is in fact not at all foreign. It is different from some (imagined, "real") Islam out there in the Middle East. It is uniquely "Indian." The genius of India's civilization, through this argument, is its "tolerance," its "absorptive" capacity, its "syncretism." What is interesting in this story, of course is the fact that it connotes nationalism in a mirror version, but, perhaps what is even more interesting it seems to me, is the fact that it implicitly takes for 
granted that "real" Islam-perhaps Arab Islam is foreign, intolerant, rigid, and so forth. This argument serves as a kind of "liberal," inclusive nationalism. Given academics' penchant for this kind of political position, we find in relation to Islam in the Indian subcontinent, an abundance of studies of Sufi shrines, devotional music, life cycle rituals, and always, always, the $16^{\text {th }}$ century Mughal Akbar, whom Amartya Sen, the Nobel prize winning economist and public intellectual, turns into a modern liberal. And the new Bollywood crossover film "Jodha Akbar" gives us a reason: Akbar is different from all the other Mughals, all the other Muslims-in this case, thanks to the influence of his Hindu wife (New York Times). The fact that Akbar is so singled out is a reminder that this mirror version of the history of Islam carries within itself unspoken assumptions of the orginal story as well.

Partha Chatterjee calls this second story the "domestication" of Islam. He writes, "The idea of the singularity of national history has inevitably led to a single source of Indian tradition, namely ancient Hindu civilization. Islam here is either the history of foreign conquest, or a domesticated element of everyday popular life [italics added] (Chatterjee 1993:113). "Domestication," ironically, implicitly confirms all the bad things that are already "known." One is better off closing one's eyes not only to conquest per se, but to South Asia's traditions of Islamic scholarship, canonical rituals, shari $a$ institutions and so forth, which would disrupt the theory of domestication that seems to offer so much hope.

\section{Stories in Southeast and East Asia}

Going beyond South Asia to Asia as a whole, stories about Muslims are, again, largely forged in a national or nationalist context. At times it seems that East Asia tends more toward the model of depicting Muslims as foreigners, and in Southeast Asia, the model of a "domesticated" Islam in much of public life and even scholarship is often expressed.

In the latter area, again, a kind of local Islam is posed against a Middle Eastern Islam. Thus the Wikipedia article on Islam in Malaysia explains that "Islam came to Malaysia with the Indian 
traders from South India and was not of the more orthodox Islamic tradition of Arabia. Islam was adopted peacefully by the coastal trading ports people of Malaysia and Indonesia, absorbing rather than conquering existing beliefs." Similar arguments are made about a peaceful Islam, historically coexisting with other religious traditions, in Indonesia, Singapore, Thailand, and the Philippines. Recent separatist movements in the latter two countries or movements calling for strict reformist standards may, therefore, treated as aberrant. As the Dutch anthropologist Martin van Bruinnessen writes in relation to Indonesia

To foreign observers as well as to many Indonesians themselves, Indonesian Islam has always appeared to be very different from Islam at most other places, especially from the way it is practiced in the Arabian peninsula.... especially in Java, Islam was not more than a thin veneer, underneath which one could easily discern an oriental worldview that differed in essential respects from the transcendentalism and legal orientation of Middle Eastern Islam. The religious attitudes of the Indonesians, it was often said, were more influenced by the Indian religions (Hinduism, Buddhism) that had long been established in the Archipelago and the even older indigenous religions with their ancestor cults and veneration of earth gods and a plethora of spirits. ${ }^{5}$

Van Bruinessen goes on, however, to make two extremely important points. One is that such judgments were typically made by people who had never observed, or chose to ignore the diversity of practice in what are taken as core Muslim areas of the Middle East. These may in fact, include some cases when the source of what is assumed to be aberrant practice is situated, when contrasted with a reified, textual Islam. Second, such a story marginalizes and makes foreign, even dangerous, rich traditions of cosmopolitan Sufism and Islamic scholarly learning, Today such interpretations may be used to position 
Southeast Asian states globally in order to contrast them with images of Muslims as "Wahhabis" and "Taliban." But they also have served historically as part of indigenous contestations within an Islam which have many competing strands, including new interpretations that find stories about "syncretism" a way of condemning popular practices in favor of new standards. Thus, these generalizations about Islam in this region as inherently "syncretic," "tolerant," or whatever, should not be taken as fact simply because Southeast Asians also say them, but seen rather as positions that serve certain kinds of political or cultural goals. They also need to be recognized, in the historian William Roff's famous phrase, as stories that give us an "Islam Obscured." 6

The images produced about Muslims in China are similarly ones produced in the context of modern nationalism, presumably making them one of the marginalized groups (as Dru Gladney writes [2004]) against which the Han Chinese have identified themselves. Muslims in China are imagined, about half of them, as distinctive Hui, on the one hand, scattered throughout the country and ethnically and linguistically indistinguishable from Han Chinese. This population in turn distinguishes itself from the Uigur and other Turkic Muslims of China's far west. Even so, Paul Theroux, the travel writer, claims in writing about Muslims generally that "Muslims have been in China for well over a thousand years and yet they are still regarded as strange and inscrutable and backward, and politically suspect" (in Forbes 2001). They are thus always at risk for the "foreign" label, so dangerous to anyone so named in our continuing era of nationalism. Again, the "work" of images like these in sustaining particular ideologies must always be distinguished from the actual histories of Muslim populations over time.

\section{Conclusion: Challenging Stereotypes, Abandoning "Culture Talk"}

What constitutes successful college teaching? Recently Mark Edmundson, writing in The New York Times, made a provocative argument that the key to successful teaching, whether in biology or in the kind of disciplines taught by Asianists, 
was the ability to see a subject afresh, to present it in a way that challenged students' preconceived notions. He explained his argument as follows:

Because really good teaching is about not seeing the world the way that everyone else does. Teaching is about being what people are now prone to call "counterintuitive" but to the teacher means simply being honest. The historian sees the election not through the latest news blast but in the context of presidential politics from George Washington to the present. The biologist sees a natural world that's not calmly picturesque but a jostling, striving, evolving contest of creatures in quest of reproduction and survival. The literature professor won't accept the current run of standard clichés but demands bursting metaphors and ironies of an insinuatingly serpentine sort. The philosopher demands an argument as escape proof as an iron box: what currently passes for logic makes him want to grasp himself by the hair and yank himself out of his seat.

The discussions in public life and even in some of our textbooks that describe Islam and Muslims may make some teachers feel the same way. Teaching about Muslims and Islam in Asia cries out for voices able to show the way the images and the narratives about Muslims have been constructed in specific historical and political contexts that may not be true to the populations they purport to describe. Above all, in our modern world, these contexts are driven by nationalist ideologies that should be part of our data, not taken as accurate representations of the people we hope to study. One of the contrarian stances we must most urgently need to take is the need to bracket "Islam" as our explanation of everything Muslims do-to abandon what Mahmud Mamdani in his aptly title book, Good Muslim, Bad Muslim, calls "culture talk" (Mamdani 2004). Arguably we learn more about Mahmud of Ghazna from studying the Cholas than from reading the Qur'an, just to take one example. 
To turn from the eleventh century to the present, for all of the understandable despair over the appalling lack of cultural literacy about Islam in public life, important though that is, surely our leaders, and all of us as citizens, would often do better to figure out that Muslims are motivated not by something obscurantist and fanatical but by just about everything that motivates everyone else: nationalism, the goal of selfdetermination, elite competition and other forms of self-interest, and opportunities to lead a good and moral life. It is this larger context of Muslim life and history that our classrooms need to illuminate.

\section{Works Cited}

Chatterjee, Partha. 1993. The Nation and Its Fragments: Colonial and Postcolonial Histories. Princeton: Princeton University Press.

Edmundson, Mark. 2008. "The Way we Live: Geek Lessons." The New York Times, 21 September.

Forbes, Andrew. 2001. "The Hui: China's Most Loyal Muslims." Originally published in The Asian Wall Street Journal. http:/ /www.cpamedia.com/politics/hui_muslims_in_china/

Gilsenan, Michael, 1998. "Manager of Stories." (A review of Beyond Belief: Islamic Excursions among the Converted Peoples by V. S. Naipaul). London Review of Books, September 3. At http://www.lrb.co.uk/v20/n17/print/ gils01_html

Gladney, Dru. 2004. Dislocating China: Muslims, Minorities, and Other Subaltern Subjects. Chicago: University of Chicago Press.

Mamdani, Mahmood. 2004. Good Muslim, Bad Muslim: America, the Cold War, and the Roots of Terror. New York: Random House.

Naipaul, V. S. 1981. Among the Believers: An Islamic Journey. New York, Alfred A. Knopf.

Naipaul, V. S. 1998. Beyond Belief: Islamic Excursions among the Converted Peoples. New York: Random House.

Thapar, Romila. 2005. Somanatha: The Many Voices of a History. London: Verso 


\section{Endnotes}

${ }^{1}$ I am grateful to Lisa Trivedi for inviting me to speak on this subject at the annual meeting of the New York Conference on Asian Studies, held at Hamilton College, Clinton New York, 29 September 2008, and to colleagues at both the talk and conference generally for their stimulating questions and presentations. The talk overlaps in part with my introduction to an anthology of primary sources, Islam in South Asia in Practice (Princeton: Princeton University Press, forthcoming [2009]).

${ }^{2}$ H.M. Elliot and John Dowson, trans. and eds., The History of India as Told by its Own Historians, 8 vols. (Allahabad: Kitab Mahal, n.d.), 1:xxi.

${ }^{3}$ Ibid., 1:xxii, xxvii.

${ }^{4}$ http://en.wikipedia.org/wiki/Islam_in_Malaysia

5 "Global and local in Indonesian Islam", Southeast Asian Studies (Kyoto) vol. 37, no.2 (1999), 46-63. http:// www.let.uu.nl/ martin.vanbruinessen/personal/publications/ Bruinessen_Global_and_local_in_Indonesian_Islam.pdf

${ }^{6}$ William R. Roff, "Islam Obscured? Some Reflections on Studies of Islam and Society in Southeast Asia," Archipel 29 (1985): 7-34 


\section{Appendix: \\ APPROXIMATE POPULATIONFIGURES}

from CIA: The World Factbook

(https://www.cia.gov/library/publications/the-world-factbook/ index.html 9/18/08)

\section{SOUTHASIA}

Pakistan

India

Bangladesh

Afghanistan

Sri Lanka

Nepal

Maldives

\section{SOUTHEASTASIA}

Indonesia

Malaysia

Philippines

Thailand

Burma/Myanmar

\section{CENTRALASIA}

Uzbekistan

Kazakhstan

Tajikistan

Turkmenistan

Kyrgyzstan

\section{EASTASIA}

China
$164 \mathrm{~m}(95 \%$ of $173 \mathrm{~m})$

$154 \mathrm{~m}$ ( of $13.4 \%$ of $1,148 . \mathrm{m}$ )

$128 \mathrm{~m}(83 \%$ of $154 \mathrm{~m})$

$32.6 \mathrm{~m}(99 \%$ of $33 \mathrm{~m})$

$1.6 \mathrm{~m}(7.6 \%$ of $21 \mathrm{~m})$

$1.3 \mathrm{~m}(4.2 \%$ of $30 \mathrm{~m})$

$386 \mathrm{k}(100 \%)$

$204 \mathrm{~m}$ ( $86 \%$ of $238 \mathrm{~m})$

$14 \mathrm{~m}(50 \%$ of $25 \mathrm{~m})$ [other sources: $60 \%$ ]

$4.5 \mathrm{~m}(5 \%$ of $96 \mathrm{~m})$

$3 \mathrm{~m}(5 \%$ of $65 \mathrm{~m})$

$2 \mathrm{~m}(4 \%$ of $48 \mathrm{~m})$

$24 \mathrm{~m}(88 \%$ of $27 \mathrm{~m})$

$7 \mathrm{~m}(47 \%$ of $15 \mathrm{~m})$

$6.3 \mathrm{~m}(90 \%$ of $7 \mathrm{~m})$

$4.5 \mathrm{~m}(89 \%$ of $5 \mathrm{~m})$

$3.8 \mathrm{~m}(75 \%$ of $5 \mathrm{~m})$

$13 m-26 m(1-2 \%$ of $1,330 m)$ 